\title{
Module Changeability On Software Quality Measurement Of Municipal Government Inventory System
}

\author{
Fikri Fadlillah ${ }^{1, *}$ \\ 1 Teknik Informatika; Universitas Gunadarma; JI Margonda Raya No. 100 Depok, \\ (021)-78881112; \\ * Korespondensi: e-mail: fikri.fadlillah@staff.gunadarma.ac.id
}

Diterima: 29 Mei 2020; Review: 30 Mei 2020; Disetujui: 5 Juni 2020; Diterbitkan: 17 Juni 2020

\begin{abstract}
Inventoring have a function to report the budget realization in the municipal region. SIMSEDIA is an application that helps SKPD on Pekalongan city shall administer the inventory. The purpose of this study was to measure the quality of software SIMSEDIA to determine which features are likely to be developed. The measurement method referring to ISO 9126 models and objectoriented metrics. Measuring the quality specified in the aspect of changeability. The research method consists of:(1) Business Process Review, (2) Module Review, (3) Tools Selection, (4) Modul Measurement, and (5) Result. The results of this study will be a barometer of changeability of SIMSEDIA at the Municipal Government in the development of inventory system to be more optimal.
\end{abstract}

Keywords: coupling, inventory, metrics, module, simsedia

\section{Introduction}

Pekalongan City Government has 62 SKPD, each departments have different characteristics, such as the use of different types of inventory, and standard operating procedures of supplies can vary from one SKPD to another. SIMSEDIA used by 62 SKPD should be able to be modified and enhanced features to easily accommodate the different characteristics of each SKPD, government regulations, and the concept of development of Management Information Systems, namely flexibility, as the characteristic which demonstrates the ability of information systems to adapt itself to the changes occurred in the prior functionality may be an obstacle to generate a response to the satisfaction of user needs within an organization[Soriano, 2012]. Management information system that's flexible enough to handle changes to the information needs of the organization known as an open system that interacts continuously with the business environment with a unified mechanism to provide the desired information from any new requirements on management.

\section{Research Methods}

\subsection{Business Process Review}

[Pamudi, 2010] stated that the business process is a mixture between sub processes are mutually coordinated with one another to achieve a predetermined goal. Business Process talk 
about how the work is done from a series of component inputs into outputs. Review business processes in SIMSEDIA include business process modeling outline of SIMSEDIA, including use case and activity diagrams modeling.

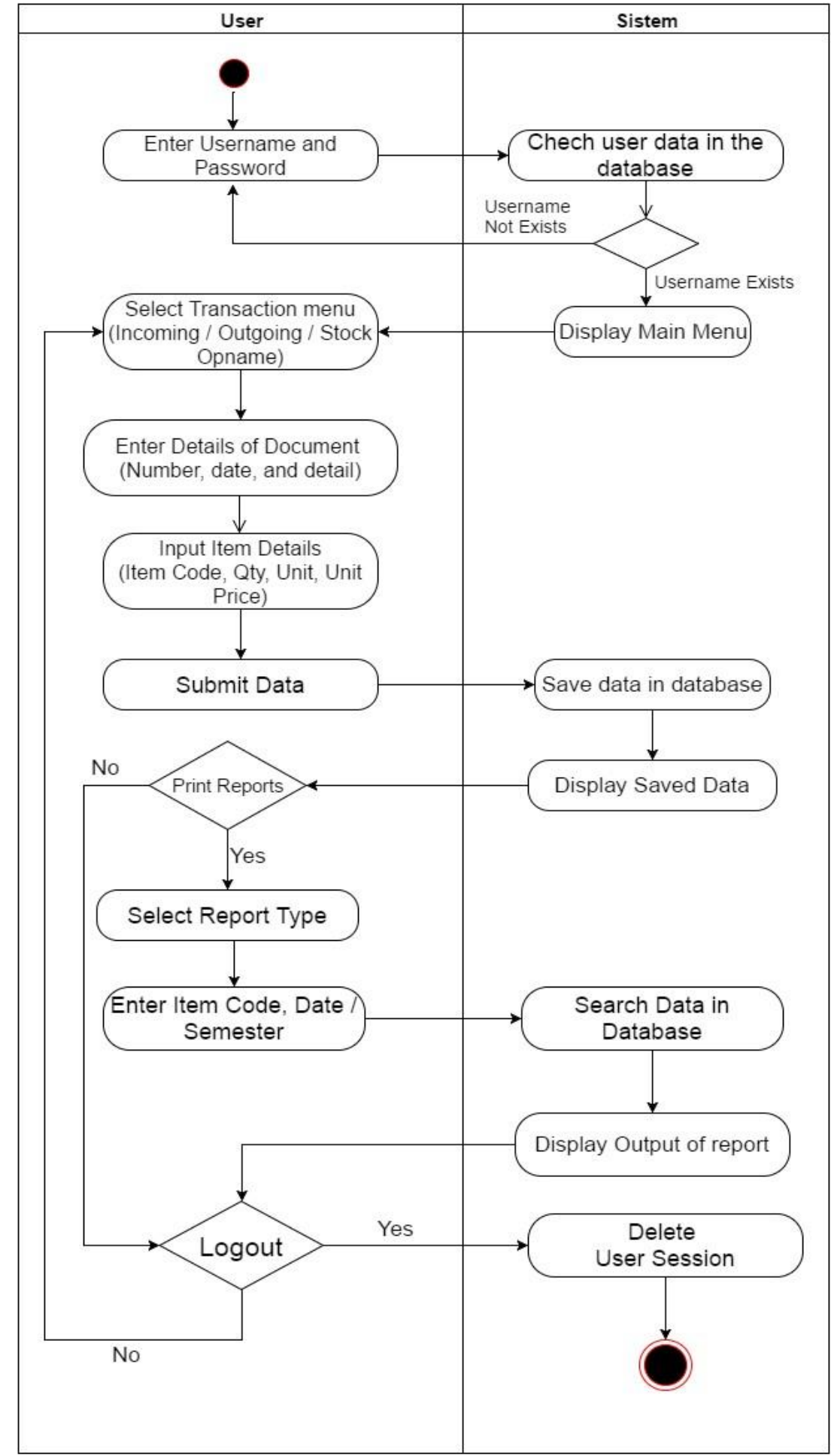

Figure 1. Business Process in SIMSEDIA 


\subsection{Module Review}

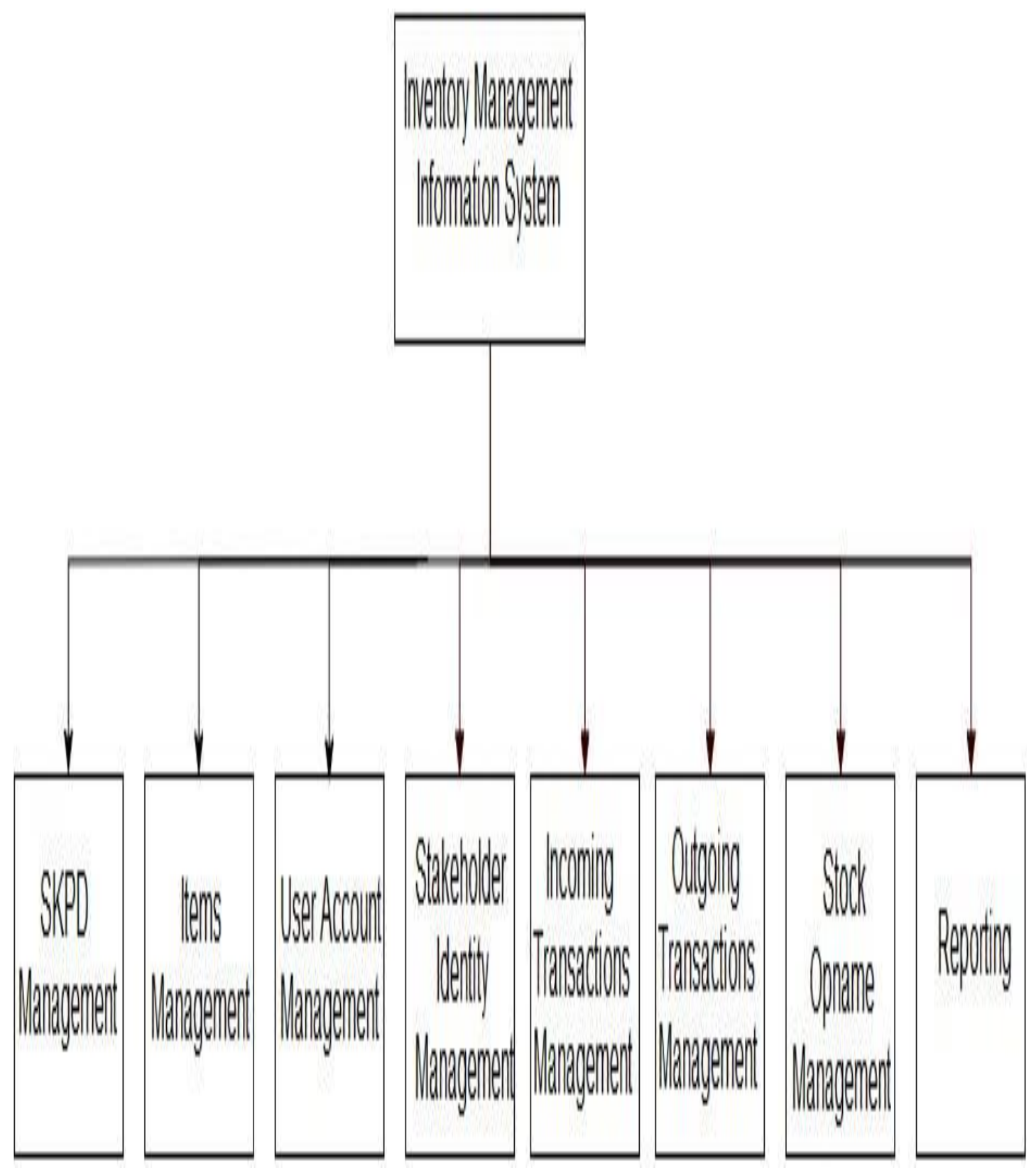

Figure 2. SIMSEDIA Modules

At this stage, review modules are done on SIMSEDIA. The module is a relatively independent group known in the statement related programs and can be viewed as a unit [Zulkifli Amsyah 2005]. Modules at SIMSEDIA shown in the figure 1 below.

\subsection{Tools Selection}

At this stage, the election of the tools used to measure the modules that have been separated before. Tools that have had to meet several criteria, including:

- Supports measurement with object oriented metrics.

- Support PHP language 


\section{Fikri Fadlillah}

- Be able to calculate parameters according to Chidamber \& Kemerer metrics

Tools that support these criteria is PhpDepend, where small programs that perform static code analysis on a specific source code. Static code analysis shows that PhpDepend the first time will take the source code and parse the source code into an internal data structure that can be easily processed.

\subsection{Module Measurement}

Measurements on each module using object oriented design metrics, which refers to the model of Chidamber and Kemerer and Martin. The parameters used for the measurement is a parameter that reflects the changeability aspects proposed by [Ayalew and Mguni, 2013]. The list of parameters used in the measurement will be outlined in table 1.

Table 1: Measurement Parameter

\begin{tabular}{lll}
\hline Parameter & Description & Category \\
\hline $\begin{array}{l}\text { Afferent Coupling } \\
(\mathrm{Ca})\end{array}$ & $\begin{array}{l}\text { The number of classes that depend on a } \\
\text { specific class.[Arapidis, 2012] }\end{array}$ & \\
\hline Efferent Coupling & The number of classes in which a class & Coupling \\
$(\mathrm{Ce})$ & depends on the specific class.[Arapidis, & \\
& 2012] & \\
\hline Coupling Between & The amount of a class that is paired with Coupling \\
Objects (CBO) & another class that occurs through method \\
& calls, access variables, inheritance, \\
& arguments, return type and exceptions. \\
& (Chidamber \& Kemerer, 1994) & \\
\hline Weight Method per & Number complexity of a method Complexity \\
Class (WMC) & $\begin{array}{l}\text { declared in a class (Chidamber \& } \\
\text { Kemerer, 1994) }\end{array}$ \\
\hline
\end{tabular}

\section{Result And Analysis}

Pseudocode are implemented in the source code contained in the attachment list. Source code is measured using PHPDepend and generate value of results. Measurement Results of afferent coupling using PHPDepend tools are outlined in Table 2.

Table 2 : Result of Efferent Coupling Measurement

\begin{tabular}{llccccccc}
\hline Class Type & Class Name & \multicolumn{2}{c}{ Value } & \multicolumn{2}{c}{ Range } & \multicolumn{2}{c}{ Criteria } \\
\cline { 2 - 8 } & & $\mathrm{Ca}$ & $\mathrm{Ce}$ & $\mathrm{Ca}$ & $\mathrm{Ce}$ & $\mathrm{Ca}$ & $\mathrm{Ce}$ \\
\hline Configuration & authenticate & 0 & 3 & $0 \leq 7$ & $3 \leq 6$ & Good & Good
\end{tabular}




\begin{tabular}{|c|c|c|c|c|c|c|c|}
\hline \multirow[t]{2}{*}{ Class Type } & \multirow[t]{2}{*}{ Class Name } & \multicolumn{2}{|c|}{ Value } & \multicolumn{2}{|c|}{ Range } & \multicolumn{2}{|c|}{ Criteria } \\
\hline & & $\mathrm{Ca}$ & $\mathrm{Ce}$ & $\mathrm{Ca}$ & $\mathrm{Ce}$ & $\mathrm{Ca}$ & $\mathrm{Ce}$ \\
\hline Configuration & config & 1 & 0 & $1 \leq 7$ & $0 \leq 6$ & Good & Good \\
\hline Configuration & mysql_db & 12 & 0 & $7<12<39$ & $0 \leq 6$ & Reg. & Good \\
\hline Model & ModelBarang & 4 & 1 & $4 \leq 7$ & $1 \leq 6$ & Good & Good \\
\hline Model & ModelSektor & 1 & 1 & $1 \leq 7$ & $1 \leq 6$ & Good & Good \\
\hline Model & ModeSatker & 3 & 1 & $3 \leq 7$ & $1 \leq 6$ & Good & Good \\
\hline Model & ModelUnit & 1 & 1 & $1 \leq 7$ & $1 \leq 6$ & Good & Good \\
\hline Model & ModelGudang & 1 & 1 & $1 \leq 7$ & $4 \leq 6$ & Good & Good \\
\hline Model & ModelUser & 1 & 1 & $1 \leq 7$ & $1 \leq 6$ & Good & Good \\
\hline Model & ModelTtd & 1 & 1 & $1 \leq 7$ & $1 \leq 6$ & Good & Good \\
\hline Model & ModelTransaksi & 1 & 4 & $1 \leq 7$ & $4 \leq 6$ & Good & Good \\
\hline Model & ModelOpsik & 2 & 1 & $2 \leq 7$ & $1 \leq 6$ & Good & Good \\
\hline Model & ModelReport & 1 & 4 & $4 \leq 7$ & $4 \leq 6$ & Good & Good \\
\hline Controller & prosesbarang & 0 & 1 & $0 \leq 7$ & $1 \leq 6$ & Good & Good \\
\hline Controller & prosessektor & 0 & 1 & $0 \leq 7$ & $1 \leq 6$ & Good & Good \\
\hline Controller & prosessatker & 0 & 1 & $0 \leq 7$ & $1 \leq 6$ & Good & Good \\
\hline Controller & prosesunit & 0 & 1 & $0 \leq 7$ & $1 \leq 6$ & Good & Good \\
\hline Controller & prosesgudang & 0 & 1 & $0 \leq 7$ & $1 \leq 6$ & Good & Good \\
\hline Controller & prosesuser & 0 & 1 & $0 \leq 7$ & $1 \leq 6$ & Good & Good \\
\hline Controller & prosesTtd & 0 & 1 & $0 \leq 7$ & $1 \leq 6$ & Good & Good \\
\hline Controller & prosestransaksi & 0 & 1 & $0 \leq 7$ & $1 \leq 6$ & Good & Good \\
\hline Controller & prosesopsik & 0 & 1 & $0 \leq 7$ & $1 \leq 6$ & Good & Good \\
\hline Controller & prosesreport & 0 & 1 & $0 \leq 7$ & $1 \leq 6$ & Good & Good \\
\hline
\end{tabular}

Measurement Results of afferent coupling using PHPDepend tools are outlined in Table 3. 
Table 3. Result of Efferent Coupling Measurement

\begin{tabular}{|c|c|c|c|c|c|c|c|}
\hline \multirow[t]{2}{*}{ Class Type } & \multirow[t]{2}{*}{ Class Name } & \multicolumn{2}{|c|}{ Value } & \multicolumn{2}{|c|}{ Range } & \multicolumn{2}{|c|}{ Criteria } \\
\hline & & CBO & WMC & CBO & WMC & CBO & WMC \\
\hline Configuration & authenticate & 3 & 4 & $3 \leq 6$ & $4 \leq 11$ & Good & Good \\
\hline Configuration & config & 0 & 3 & $0 \leq 6$ & $3 \leq 11$ & Good & Good \\
\hline Configuration & mysql_db & 0 & 30 & $0 \leq 6$ & $11<30<34$ & Good & Regular \\
\hline Model & ModelBarang & 1 & 22 & $1 \leq 6$ & $11<22<34$ & Good & Regular \\
\hline Model & ModelSektor & 1 & 6 & $1 \leq 6$ & $6 \leq 11$ & Good & Good \\
\hline Model & ModeSatker & 1 & 25 & $1 \leq 6$ & $11<25<34$ & Good & Regular \\
\hline Model & ModelUnit & 1 & 8 & $1 \leq 6$ & $8 \leq 11$ & Good & Good \\
\hline Model & ModelGudang & 1 & 15 & $1 \leq 6$ & $11<15<34$ & Good & Regular \\
\hline Model & ModelUser & 1 & 13 & $1 \leq 6$ & $11<13<34$ & Good & Regular \\
\hline Model & ModelTtd & 1 & 18 & $1 \leq 6$ & $11<18<34$ & Good & Regular \\
\hline Model & ModelTransaksi & 4 & 101 & $4 \leq 6$ & $101>34$ & Good & Bad \\
\hline Model & ModelOpsik & 1 & 28 & $1 \leq 6$ & $11<28<34$ & Good & Regular \\
\hline Model & ModelReport & 4 & 214 & $4 \leq 6$ & $214>34$ & Good & Bad \\
\hline Controller & prosesbarang & 1 & 14 & $1 \leq 6$ & $11<14<34$ & Good & Regular \\
\hline Controller & prosessektor & 1 & 6 & $1 \leq 6$ & $6 \leq 11$ & Good & Good \\
\hline Controller & prosessatker & 1 & 8 & $1 \leq 6$ & $8 \leq 11$ & Good & Good \\
\hline Controller & prosesunit & 1 & 7 & $1 \leq 6$ & $7 \leq 11$ & Good & Good \\
\hline Controller & prosesgudang & 1 & 10 & $1 \leq 6$ & $10 \leq 11$ & Good & Good \\
\hline Controller & prosesuser & 1 & 7 & $1 \leq 6$ & $7 \leq 11$ & Good & Good \\
\hline Controller & prosesTtd & 1 & 13 & $1 \leq 6$ & $11<13<34$ & Good & Regular \\
\hline Controller & prosestransaksi & 1 & 31 & $1 \leq 6$ & $11<31<34$ & Good & Regular \\
\hline Controller & prosesopsik & 1 & 10 & $1 \leq 6$ & $10 \leq 11$ & Good & Good \\
\hline Controller & prosesreport & 1 & 20 & $1 \leq 6$ & $11<25<34$ & Good & Regular \\
\hline
\end{tabular}

\section{CONCLUSION}

Measuring the quality of software SIMSEDIA on parameters that reflect aspects of changeability successful. Parameter measurements carried out on the model class consists of 
10 classes, the controller class that consists of 10 classes, and configuration class that consist of 3 classes. The results using the tools PHPDepend for measuring parameters reflecting aspects of changeability in each class obtained value Afferent Coupling $(\mathrm{Ca})$ high of 12 by class mysql_db, value Efferent Coupling (Ce) and Coupling Between Objects (CBO) is the highest of four by class ModelReport and ModelTransaksi, as well as the value Weighted Methods per Class (WMC) is the highest of 214 by ModelReport class.

\section{References}

Ainapure, B. (2017). "Software Testing and Quality Assurance,". Technical Publication India Arapidic, C. (2012). "Sonar Code Quality Assurance,". Packt Publishing UK

Ayalew, Y. and Mguni, K., "An assessment of cangeability of open source software," Computer and Information Science, vol 6, pages 68-79, 2013

Bastian, I. (2006). "Akuntansi Sektor Publik : Suatu Pengantar,". Erlangga Jakarta

BPS Statistics 2016 about Pekalongan Municipality in Figures

Caroll, S. (2007). "Fundamental Concepts fot The Software Quality Engineer,". Packt Publishing UK

Desikan, S. (2006). "Software Testing : Principles and Practice,". Dorling Kindersley India

et. al., J. M. Z. (2011). "Software Engineering and Computer Systems". Springer Hidelberg Dordrecht New York

Fito, T. G. S., Bigonha, M. A.S., and Ferreire, K. A. M., "A catalogue of thresholds for objectoriented software metrics," The First International Conference on Advances and Trends in Software Engineering, 2015

Jawadekar, W. (2009). "Management Information Systems : Text \& Cases,". Tata Mcgraw Hill

Malhotra, J. J. and Tiple, B. S. (2008). "Software Testing and Quality Assurance ,. Nirali Prakashan Pune

Olive, A. (2007). "Conceptual Modeling of Information Systems,". Springer-Verlag Berlin.

Pamudi, T. S. (2010). "Riding the Wave: Strategi Andal Menaklukkan Industri Software,". Elex Media Computindo Jakarta.

Pfleeger, S. L., Wu, F., and Lewis, R. (2005). "Software Cost Estimation and Sizing Methods: Issues, and Guidelines". Pittsburgh : RAND Corporation

Rumbaugh, J., Jacobson, I., and Booch, G. (2005). The Unified Modeling Language Reference Manual. Second Edition. Pearson Education Inc

Sharma, S., et, and al. "A review of coupling and cohesion metrics in object oriented environment" International Journal of Computer Science \& Engineering Technology, volume 4, 2013

Singh, Y. and Malhotra, R. (2012). "Object Oriented Software Engineering,". PHI Learning Private Limited New Delhi.

Soemarso (2007). “Perpajakan : Pendekatan Komprehensif,". Salemba Empat Jakarta. 
Soriano, J. L. (2012). Maximizing Benefits from IT Project Management: From Requirements to Value Delivery. Taylor \& Francis Group.

U, P. and V., S. "Significance of coupling and cohesion on design quality," In Significance of Coupling and Cohesion on Design Quality, 2014 